\title{
Storage characteristics of watermelon before and after removing the T-shaped stalk
}

\author{
$\mathrm{Nak}^{-\mathrm{Ku}} \mathrm{Kim}^{1 *}$, Young-Ho Chang ${ }^{1}$, Su-Pil $\mathrm{Yu}^{2}$, Ki-Jeong $\mathrm{Ha}^{1}$, Hee-Jeong $\mathrm{Je}^{1}$, \\ Kwang-Pyo Hong ${ }^{1}$, Sang-Dae Lee ${ }^{1}$ \\ ${ }^{1}$ Gyeongnam Agricultural Research and Extension Services, Jinju 660-985, Korea \\ ${ }^{2}$ Haman Agriculture Technology Center, Haman 637-801, Korea
}

\section{수박의 꼭지 제거여부에 따른 저장성}

\author{
김낙구 ${ }^{*} \cdot$ 장영호 $^{1} \cdot$ 유수필 $^{2} \cdot$ 하기정 $^{1} \cdot$ 제희정 $^{1} \cdot$ 홍광표 $^{1} \cdot$ 이상대 $^{1}$ \\ ${ }^{1}$ 경상남도농업기술원, ${ }^{2}$ 함안군농업기술센터
}

\begin{abstract}
This study was carried out to compare the storage characteristics of watermelon (Citrullus lanatus) before and after removing the T-shaped stalk. For the investigation of the physiochemical properties of the watermelo, the watermelaon was stored at room temperature and $7^{\circ} \mathrm{C}$, respectively. The average weight of the watermelon $(7.8$ kg) decreased by $0.6 \sim 0.7 \%$ at $7{ }^{\circ} \mathrm{C}$ and by $1.9 \sim 2 \%$ at room temperature during the storage period of 30 days. The hardness of watermelon reduced from $755 \mathrm{~g}$ to $542 \sim 549 \mathrm{~g}$ at room temperature for 30 days. However, the existence of T-shape stalk did not significantly affect on their weight and hardness. In addition, the pH, total acid content, and inner moisture of the watermelon were not significantly changed during the storage periods while the soluble solid at room temperature was significantly decreased from $11.3{ }^{\circ}$ Brix to $9.3{ }^{\circ}$ Brix after 30 days of storage. The internal redness of the watermelon decreased from 36.7 to 31.7 33.6. The total amount of its free sugar was increased from the original amount $(8,133 \mathrm{mg} / 100 \mathrm{~g})$ and then decreased. However, the stalk did not significantly affect on the amount of total free sugar under the same storage condition, too. Thus, there was no significant difference between the results of leaving the T-shaped stalk and removing it after harvesting the watermelon.
\end{abstract}

Key words : watermelon, storage, removing stalk, T-shape stalk

\section{서 론}

우리나라 여름철 대표 과일이라면 수박이라 할 수 있다. 수박은 박과에 속하는 일년생의 덩굴풀로서 남아프리카가 원산지이며 인류가 처음 먹기 시작한 것은 약 4,000 년 전이 라고 알려진다. 우리나라에는 고려 말 원나라를 통해서 들 어왔고 서역에서 들어왔다고 하여 '서과', 물이 많다고 하여 ‘수과', 성질이 차다고 하여 ‘한과' 등으로 불렸으며 보편화

*Corresponding author. E-mail : fragrant $@$ korea.kr

Phone : 82-55-254-1442, Fax : 82-55-254-1419

Received 2 February 2015; Revised 10 April 2015; Accepted 10 April 2015.

Copyright (c) The Korean Society of Food Preservation. All rights reserved.
된 것은 조선시대이나 당시로서는 귀한 과일이었다. 이러 한 수박은 2013년 전국 $14,885 \mathrm{ha}$ 에서 673천톤이 생산되었 고, 연중 안정적으로 고품질의 수박을 생산할 수 있는 시설 재배 생산량이 $86 \%$ 로 대부분을 차지하였는데 주산지는 충남과 경남으로 전국의 $53 \%$ 를 차지한다(1).

수박은 수분이 $90 \%$ 이상이며 포도당, 과당 등 당분이 $8 \%$ 이상으로서(2) 피로회복에 좋으며 아미노산으로 요소대 사 과정의 중간 대사물질인 시트룰린(citrulline)을 함유하여 이뇨작용을 도와주며(3) 항산화작용과 항암작용이 뛰어나 며 라이코펜 함량도 $47.3 ~ 68.6 \mu \mathrm{g} / \mathrm{g}$ 으로 풍부한 과일이다(4).

이러한 수박을 수확한 후 유통단계별 포장실태를 보면 이전에는 산물출하가 대부분이라 하였는데(5) 최근에는 대 부분 농협 등의 공동선별장에서 골판지상자 등을 이용하여 포장하여 출하하며 물류개선의 일환으로 팰릿에 담아 유통 
하는 것도 추진 중이다(6).

그렇지만 현재 우리나라에서는 일본이나 미국 등 다른 나라와 달리 수박의 꼭지를 $\mathrm{T}$ 형으로 잘라서 수확한 후 수 송, 판매 등 유통이 되는데 속 품질이 좋더라도 꼭지가 떨어 지거나 시들면 가격도 매우 떨어진다. 그래서 수박꼭지의 시들음을 지연하기 위해 바셀린을 처리한 경우 무처리의 9 일에 비해 수확 15 일 후 시들었다는 Park 등의 연구(7)도 이런 차원에서 이루어져 있다. 본래 수박의 꼭지는 줄기의 일부분으로서 잎, 뿌리와 물질대사의 통로였으나 수확 후 에는 단지 신선도 판단의 수단으로서 이용될 뿐이다. 또한 선별과 라벨이 발달된 요즈음 굳이 수박꼭지를 붙여 수확하 고 판매함으로서 노동력이 많이 소요될 뿐만 아니라 유통과 정에서도 매우 불편한 것이 현실이다.

그러나 수박에 대한 연구로는 대부분 재배, 병해충과 관 련된 것(8-11) 또는 이화학적 특성이나 가공과 관련된 것이 (12-15) 대부분이며 수박꼭지의 유무와 상품성 관계를 알 수 있는 저장시험은 보고 된 바가 없다. 그래서 본 연구에서 는 수박의 꼭지가 있는 것과 없는 것이 저장성에 어떤 영향 을 주는지 알기위해, 관행대로 수박꼭지를 T형으로 남긴 것과 완전히 잘라 제거한 것으로 구분하여 저장하면서 당 도, 경도 무게 등 저장성과 관련된 여러 요인들을 조사하였다.

\section{재료 및 방법}

재 료

본 실험에 시료로 사용한 수박은 함안군 농업기술센터에 서 분양받은 “꿀수박" 품종으로 선별을 통해 가능한 크기가 비슷한 것을 이용하였다. 수박을 수확할 때에는 관행적인 방법대로 꼭지를 T형으로 남겨둔 것과 실험을 위해 완전히 제거한 것으로 구분하여 수확하였으며, 수박은 2 개들이 수 박전용 골판지 상자에 넣고 실온 및 저온저장을 하면서 시료로 사용하였다. 저온저장은 Park 등(7)의 자료를 참고 하여 $7^{\circ} \mathrm{C}$ 에서 저장하면서 저장기간 동안 무게를 비롯하여 이화학성의 변화를 조사하였다. 한 처리구는 3 개의 수박으 로 구성되었으며 평균값을 측정하였다. 일반적인 수박의 유통기간은 $10 \sim 15^{\circ} \mathrm{C}$ (습도 $90 \%$ )에서는 3 주, 실온 $\left(24^{\circ} \mathrm{C}\right)$ 에서 10 일이라 하나(16) 본 실험에서는 꼭지유무에 따른 변화와 차이를 보기 위해 30 일까지 저장하면서 조사하였다.

\section{시료의 일반성분, 색도}

저장 전 시료의 일반성분 분석은 식품공전(17)에 따라 수분은 상압가열건조법으로 조사하였고, 단백질은 킬달 (Kjeldahl)법으로 단백질추출기(Tecator 1035, Sweden)를 이용하여 측정하였으며 지방은 Soxhlet 추출법으로 측정하 였다. 회분은 직접 회화하는 방법으로, $\mathrm{pH}$ 는 $\mathrm{pH}$ meter(CG 843 , Schott, Germany)로 측정하였으며 총산은 $\mathrm{AOAC}$ 법
(18)에 따라 $\mathrm{NaOH}$ 의 적정량을 succinic acid로 환산하여 $\%$ 로 나타내었다.

당도(가용성고형분)는 자른 시료의 일정량을 취하여 거 즈로 즙을 낸 다음 휴대용 굴절당도계(ATC-1E, Atago, Tokyo, Japan) 로 측정하였고, 색도는 수박을 반으로 자르고 각각 중심부와 좌우 $5 \mathrm{~cm}$ 되는 곳을 색차계(Minolta spectrophotometer, CM-3500d, Tokyo, Japan)를 이용하여 측 정하였다.

\section{경 도}

경도는 준비한 시료를 2 등분하고 각각 texture analyzer (TA/XT 2i, Stable Micro systems Co., Surrey GU7 1YL, $\mathrm{UK}$ )를 이용하여 중심부와 좌우로 $5 \mathrm{~cm}$ 지점에 $6 \mathrm{~mm}$ 의 probe를 깊이 $20 \mathrm{~mm}$ 까지 침투시켜 3회 측정하고 그 평균값 을 한 개 시료의 처리값으로 하였다.

\section{무기성분 및 유리당}

저장전 무기성분은 Chung 등(19)의 방법을 응용하여 시 료를 습식 분해한 후 원자흡광분광광도계(Anaylst 300, Perkin-Elmer, Norwalk, USA)를 이용하여 정량하였으며, 유 리당은 Choi 등(20)의 방법을 변형하여 시료 $10 \mathrm{~g}$ 을 취하고 $\mathrm{ddH} 2 \mathrm{O} 20 \mathrm{~mL}$ 를 더하여 마쇄한 후 원심분리한 상등액을 Sep-pak C18로 통과시킨 후 $\mathrm{HPLC}$ 로 칼럼온도 $80^{\circ} \mathrm{C}$ 에서 RI detector(RID-10A, Shimadzu, Kyoto, Japan)를 이용하여 측정하였다.

\section{통계처리}

모든 데이터는 3회 이상 반복측정한 후 통계처리는 SPSS 프로그램을 이용하여 일원 분산분석(oneway ANOVA) 하 였으며, 처리간의 유의성 검정은 $\mathrm{p}<0.05$ 수준에서 실시하였 으며 그 결과는 그림아래 표시하였다.

\section{결과 및 고찰}

시험용 수박의 형태적 특성

수확한 시료의 형태적 특성을 조사하여 평균치를 구하였 는데, Table 1과 같이 가로와 세로는 각각 $23.1 \mathrm{~cm}$ 및 27.2 $\mathrm{cm}$ 였고, 무게는 $7.8 \mathrm{~kg}$ 로서 국립농산물품질관리원의 수박 표준규격 중 크기구분에 따르면 " $\mathrm{M}$ " 또는 " $\mathrm{L}$ "급 이었다 (21). 또한 과피두께는 $1.2 \mathrm{~cm}$, 가용성고형분는 $11.3^{\circ} \mathrm{Brix}$ 이었고, 수박을 반으로 잘라 측정한 내부의 색도는 명도(L) 가 44.3, 적색도(a)가 36.7 , 황색도(b)가 24.1로 Veazie와 Collins(22)가 L 37.2, a 26.9, b 13.6이라고 보고한 결과와 차이를 보였는데 이는 품종 및 재배조건이 다르기 때문이라 판단된다. 
Table 1. Morphological characteristics of the watermelon before its storage

\begin{tabular}{|c|c|c|c|c|c|c|c|}
\hline \multirow{2}{*}{$\begin{array}{c}\text { Weight } \\
\mathrm{g}\end{array}$} & \multirow[t]{2}{*}{ Width } & \multirow{2}{*}{$\begin{array}{l}\text { Length } \\
\mathrm{cm}\end{array}$} & \multirow{2}{*}{$\begin{aligned} & \text { Peel thickness } \\
\rightarrow & \end{aligned}$} & \multirow{2}{*}{$\begin{array}{l}\text { Soluble solid } \\
{ }^{\circ} \text { Brix }\end{array}$} & \multicolumn{3}{|c|}{ Hunter value ${ }^{1)}$} \\
\hline & & & & & $\mathrm{L}$ & a & $\mathrm{b}$ \\
\hline $7,831 \pm 559$ & $23.1 \pm 1.08$ & $27.2 \pm 1.07$ & $1.2 \pm 0.15$ & $11.3 \pm 0.62$ & $44.3 \pm 2.37$ & $36.7 \pm 2.35$ & $24.1 \pm 1.7$ \\
\hline
\end{tabular}

${ }^{1)} \mathrm{L}$, Lightness; a, redness; b, yellowness.

Table 2. Proximate composition and mineral contents of the watermelon before its storage

\begin{tabular}{|c|c|c|c|c|c|c|c|c|c|}
\hline Moisture & Protein & & Fat & Ash & $\mathrm{pH}$ & Total acid & $\mathrm{Mg}$ & $\mathrm{Ca}$ & K \\
\hline & $\leftarrow$ & $\%$ & $\rightarrow$ & & $(1: 5)$ & $\%$ & $\leftarrow$ & $\mathrm{mg} / 100 \mathrm{~g}$ & $\rightarrow$ \\
\hline $89.9 \pm 1.46$ & $0.8 \pm 0.06$ & & $0.3 \pm 0.05$ & $0.5 \pm 0.06$ & $5.9 \pm 0.1$ & $0.1 \pm 0.01$ & $15.6 \pm 2.5$ & $12.2 \pm 1.4$ & $194 \pm 23.6$ \\
\hline
\end{tabular}

\section{시험용 수박의 일반 성분}

Table 2는 수박의 저장시험을 실시하기 전 시료의 일반성 분 등을 조사한 결과이다. 수분은 $89.9 \%, \mathrm{pH}$ 는 5.9 , 총산은 $0.1 \%$ 였으며 무기성분의 함량은 $\mathrm{K}$ 가 $194 \mathrm{mg} / 100 \mathrm{~g}$ 으로 가장 많았고, $\mathrm{Mg}$ 은 $15.6 \mathrm{mg} / 100 \mathrm{~g}, \mathrm{Ca}$ 은 $12.2 \mathrm{mg} / 100 \mathrm{~g}$ 이 었다.

저장일수와 꼭지처리에 따른 무게변화

시료로 사용한 수박은 꼭지를 관행대로 $\mathrm{T}$ 형으로 남긴 것과 제거한 것을 $7^{\circ} \mathrm{C}$ 와 실온에 저장하면서 3 일 간격을 두고 무게를 조사하였다. 저장일수와 꼭지처리에 따른 무 게변화를 보면 저장 전 평균 $7,831 \mathrm{~g}$ 이던 것이 저장일수가 증가할수록 모든 처리에서 감소하였다. 무게감소율은 저장 온도에 따라서는 차이를 보였는데, 30 일째 $7^{\circ} \mathrm{C}$ 에서는 7,776 7,782 $\mathrm{g}$ 으로 $0.6 \sim 0.7 \%$ 감소한 반면 실온에서는 7,676 7,683 g으로 1.9 2\%나 감소하였다(Fig. 1). 같은 저장 온도조건하에서는 꼭지가 있는 것이 제거한 것에 비해 무게 감소율이 약간 높았으나 통계적 유의성은 없었다.

(A)

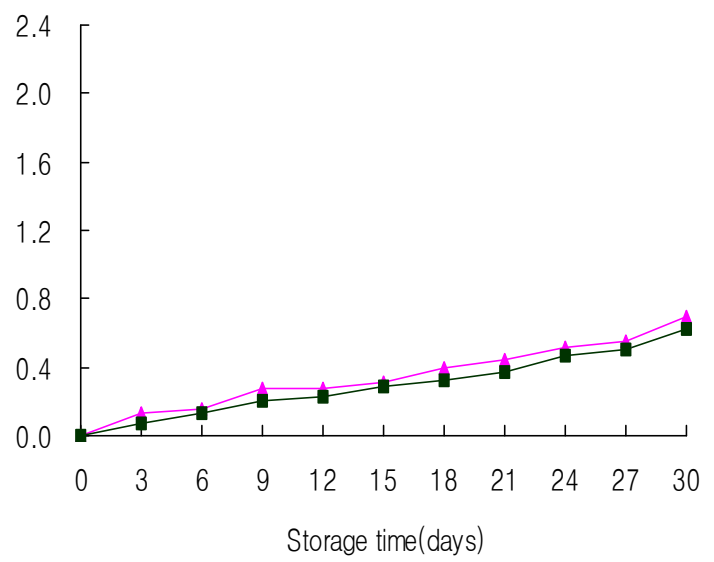

저장일수와 꼭지처리에 따른 경도변화

저장일수에 따른 경도의 변화는 6일 간격으로 조사하였 는데 결과는 Fig. 2와 같았다. 경도는 초기 $755 \mathrm{~g}$ 에서 저장일 수가 경과함에 따라 점차 감소하였으며 30 일째 $7^{\circ} \mathrm{C}$ 저장은 $662 \sim 674 \mathrm{~g}$ 실온의 경우 542 549 g으로 실온에 저장하였을 때 더 큰 감소폭을 보였다. 그러나 경도의 변화도도 같은 온도조건하에서는 꼭지유무에 따른 차이에는 유의성이 없 었다.

저장일수와 꼭지처리에 따른 $\mathrm{pH}$ 변화

저장기간의 $\mathrm{pH}$ 는 미미하게 변화하였는데 Fig. 3과 같았 다. $7^{\circ} \mathrm{C}$ 저장의 경우 초기 5.9에서 저장 30 일에는 5.6 5.7로 이었고 실온의 경우는 5.9 6.1이었으나 같은 저장조건에서 꼭지유무간의 유의차를 보이지 않았다.

저장일수와 꼭지처리에 따른 총산변화

총산은 저장기간이 경과함에 따라 시료들의 처리별 평균 치는 조금 달랐으나 초기 $0.07 \%$ 에서 후기 $0.06 ~ 0.09 \%$ 로
(B)

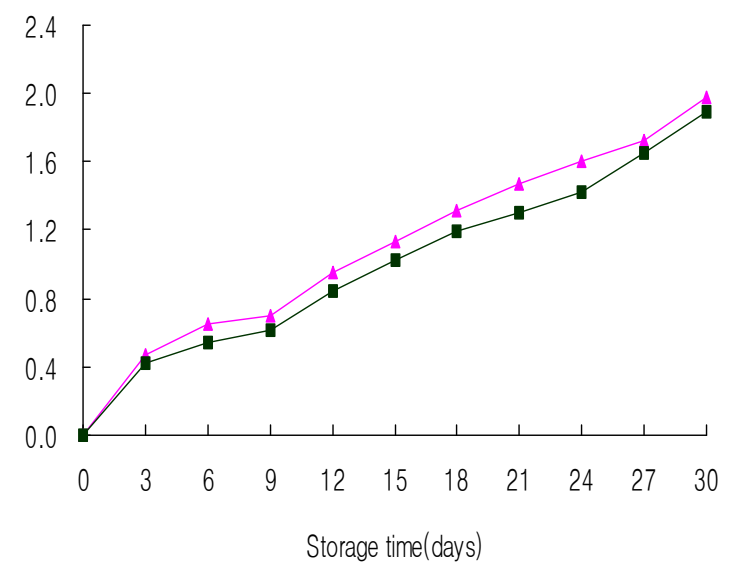

Fig. 1. Changes in the weight of the watermelon depending on its storage temperature and stalk shape during its storage.

(A), $7^{\circ} \mathrm{C}$; (B), room temperature. $\mathbf{\square}$, watermelon without stalk; $\boldsymbol{\Delta}$, water melon with T-type stalk. There is no significant difference within columns, $p<0.05$. 
(A)

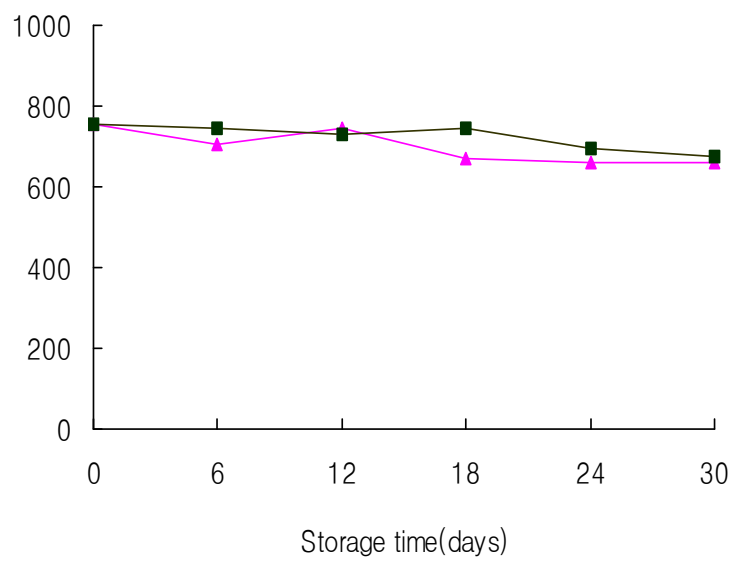

(B)

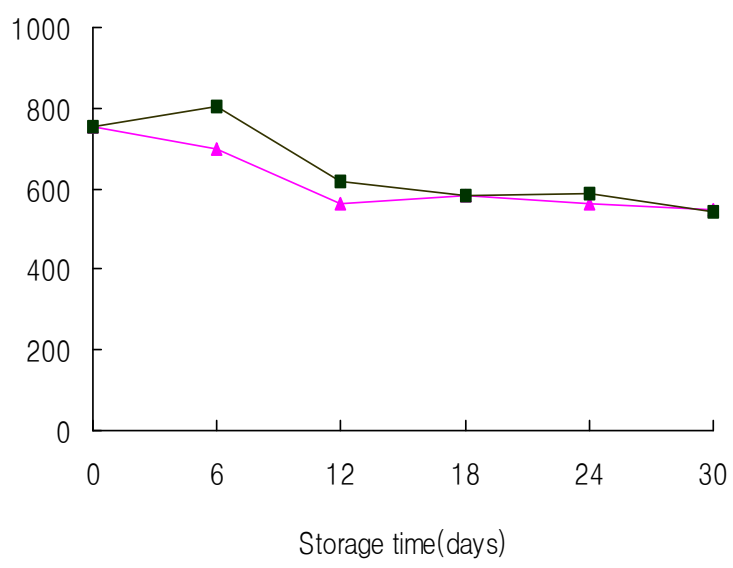

Fig. 2. Changes in the hardness of the watermelon depending on its storage temperature and stalk shape during its storage. (A), $7^{\circ} \mathrm{C}$; (B), room temperature. $\mathbf{\square}$, watermelon without stalk; $\boldsymbol{\Delta}$, water melon with T-type stalk. There is no significant difference within columns, $p<0.05$.

(A)

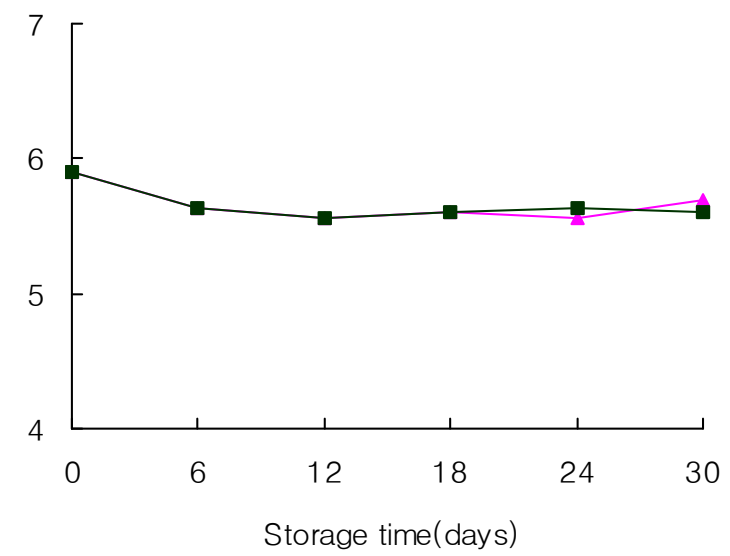

(B)

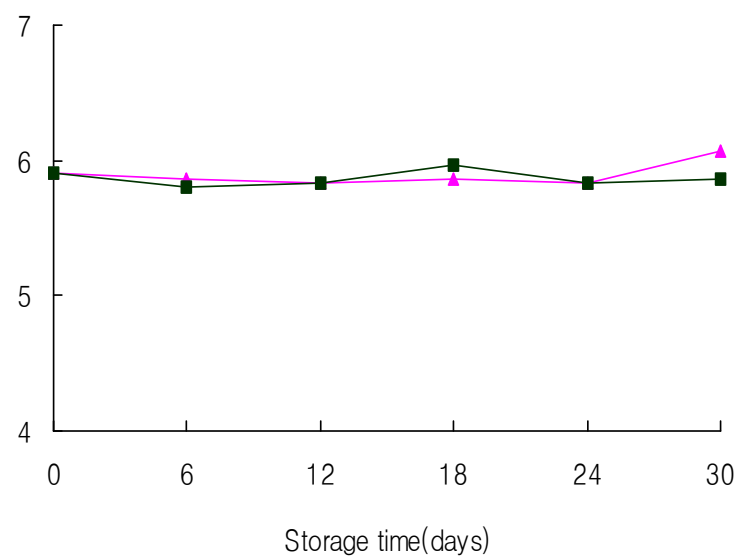

Fig. 3. Changes in the $\mathrm{pH}$ of the watermelon depending on its storage temperature and stalk shape during its storage.

(A), $7^{\circ} \mathrm{C}$; (B), room temperature. $\mathbf{\square}$, watermelon without stalk; $\boldsymbol{\Delta}$, water melon with T-type stalk. There is no significant difference within columns, $p<0.05$.

(A)

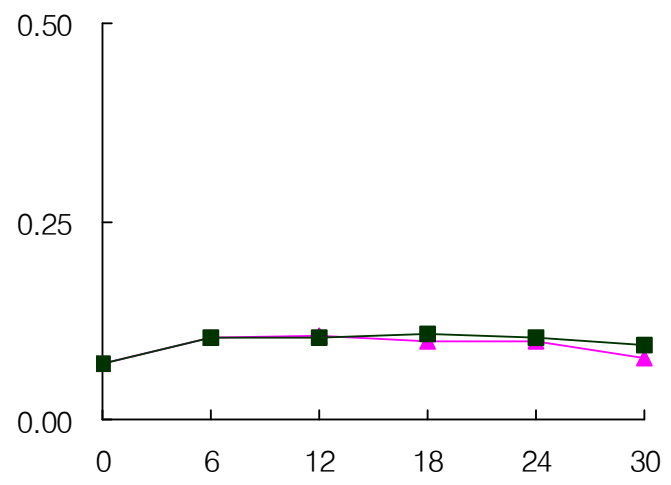

Storage time(days)
(B)

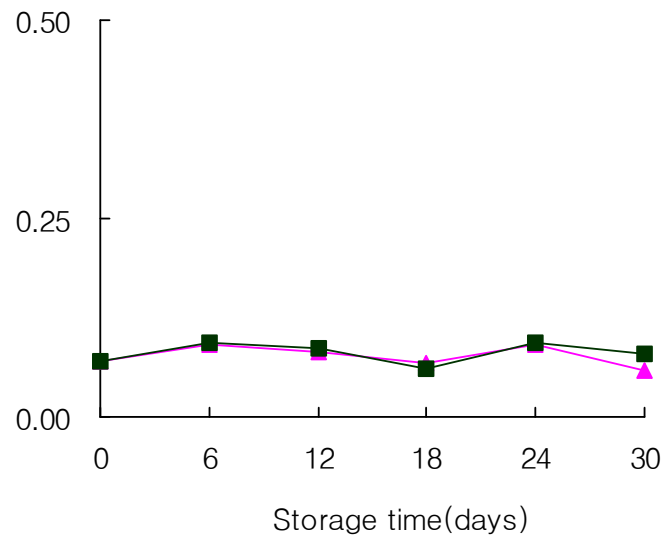

Fig. 4. Changes in the total acid content of the watermelon depending on its storage temperature and stalk shape during its storage. (A), $7^{\circ} \mathrm{C}$; (B), room temperature. $\mathbf{\square}$, watermelon without stalk; $\boldsymbol{\Delta}$, water melon with T-type stalk. There is no significant difference within columns, $\mathrm{p}<0.05$. 
그 변화와 차이는 극히 미미하였으며(Fig. 4), 저장온도와 꼭지유무에 따른 총산의 변화도 유의차를 보이지 않았다.

저장일수와 꼭지처리에 따른 당도(가용성고형분)변화

Chisholm 등(23)은 두 품종의 수박을 저장하면서 가용성고 형분을 조사한 결과 $0^{\circ} \mathrm{C}$ 에서는 거의 변화가 없었으나 $20^{\circ} \mathrm{C}$ 이 상에서는 크게 감소하였다고 보고하였다. 본시험에서도 가용 성고형분은 Fig. 5와 같이 저장일수가 경과함에 따라 감소하였 는데 $7^{\circ} \mathrm{C}$ 저장에서는 초기와 큰 차이가 없었으나, 실온에 저장 한 것은 꼭지유무와 관계없이 초기 평균 $11.3^{\circ} \mathrm{Brix}$ 에서 30 일 후에는 $9.3^{\circ} \mathrm{Brix}$ 로서 크게 감소하였다. 그러나 같은 저장조건 에서 꼭지의 유무에 따른 유의차는 보이지 않았다.

저장일수와 꼭지처리에 따른 수분 변화

저장기간에 따른 내부 수분함량은 초기 $89.9 \%$ 에서 저장
온도 및 꼭지유무와 상관없이 저장기간에 따라 미미한 증가 를 보였는데(Fig. 6), 이는 저장기간이 경과하면서 연화에 따른 과육세포 속의 수분이 용출되었고 수박의 과피가 두꺼 우므로 내부수분이 발산될 수 없었기 때문으로 생각된다. 수분 역시 동일한 저장조건에서 꼭지 유무에 따른 수분함량 의 변화는 유의차를 보이지 않았다.

저장일수와 꼭지처리에 따른 적색도(a) 변화

수박은 과피의 독특한 줄무늬와 내부의 붉은 색으로 대 표된다. 본시험에서는 수박을 자른 후 내부의 적색도의 변 화를 관찰하였는데 Fig. 7에 나타낸 것처럼 적색도는 꼭지 유무나 저장온도와 관계없이 초기 36.7에서 저장후기에는 31.7 33.6으로 감소하였으나 꼭지유무에 따른 유의차는 없 었다.
(A)

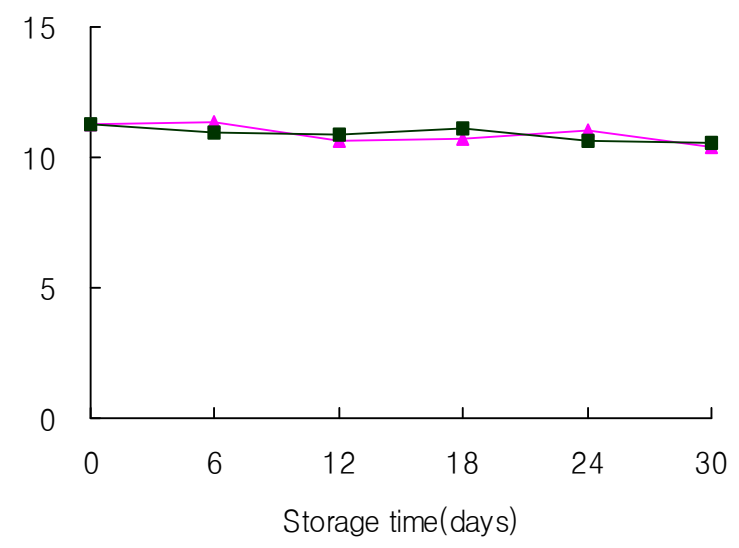

(B)

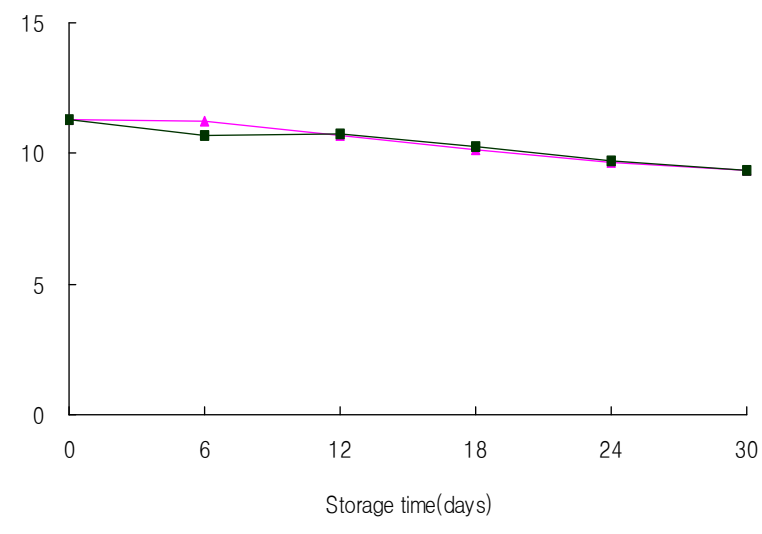

Fig. 5. Changes in the soluble solid content of the watermelon depending on its storage temperature and stalk shape during its storage. (A), $7^{\circ} \mathrm{C}$; (B), room temperature.

, watermelon without stalk;

, water melon with T-type stalk. There is no significant difference within columns, $\mathrm{p}<0.05$.

(A)

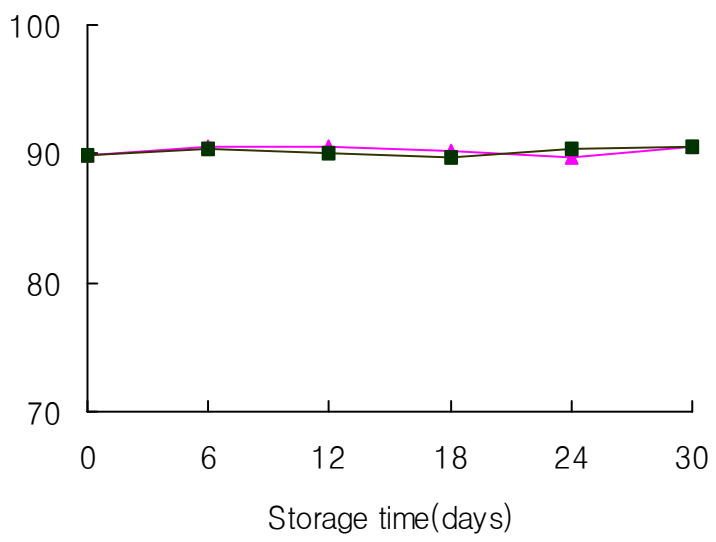

(B)

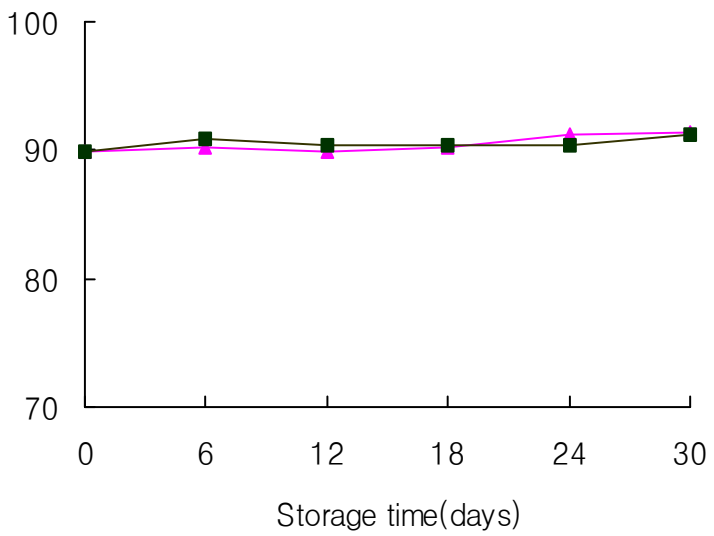

Fig. 6. Changes in the moisture of the watermelon depending on its storage temperature and stalk shape during its storage.

(A), $7^{\circ} \mathrm{C}$; (B), room temperature. $\mathbf{\square}$, watermelon without stalk; $\mathbf{\Delta}$, water melon with $\mathrm{T}$-type stalk. There is no significant difference within columns, $\mathrm{p}<0.05$. 
(A)

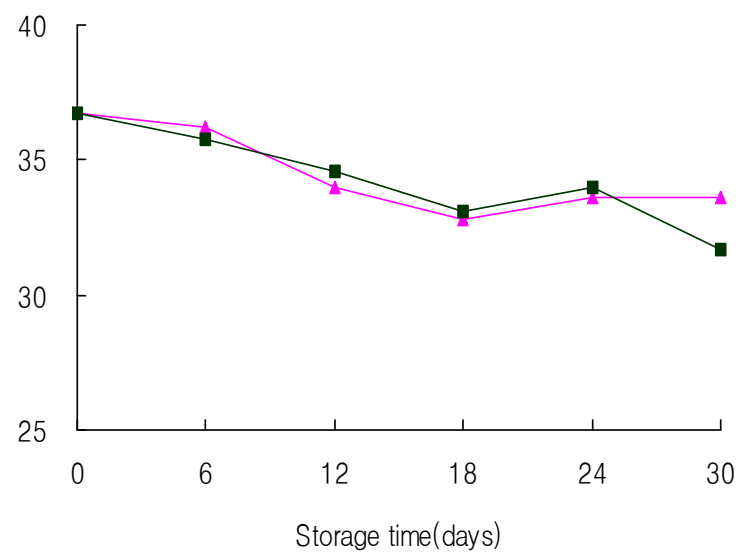

(B)

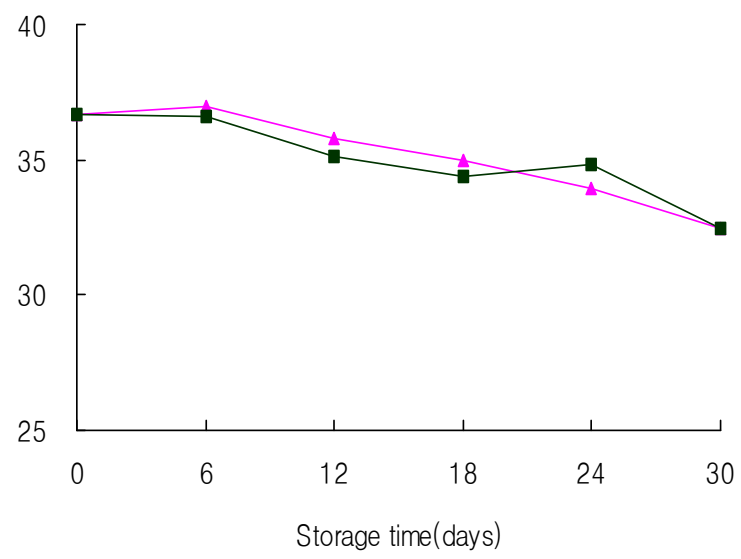

Fig. 7. Changes in the redness (Hunter's a value) of the watermelon depending on its storage temperature and stalk shape during its storage. (A), $7^{\circ} \mathrm{C}$; (B), room temperature.

watermelon without stalk;

A, water melon with T-type stalk. There is no significant difference within columns, $p<0.05$.

(A)

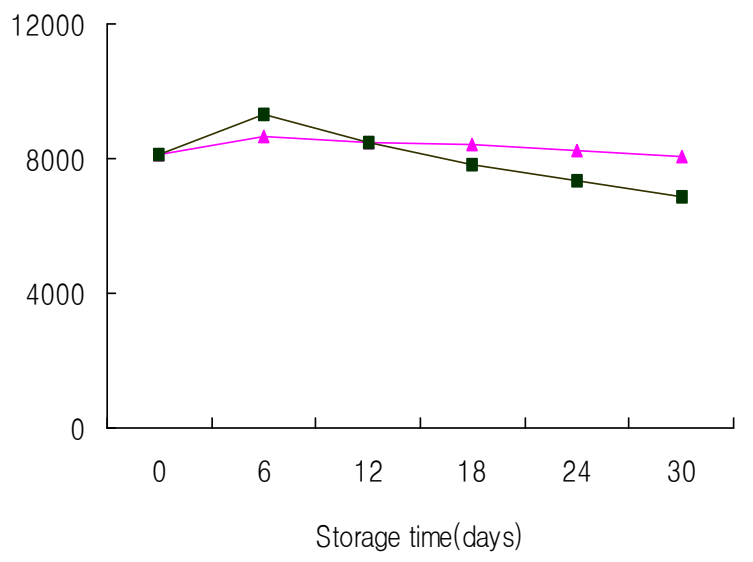

(B)

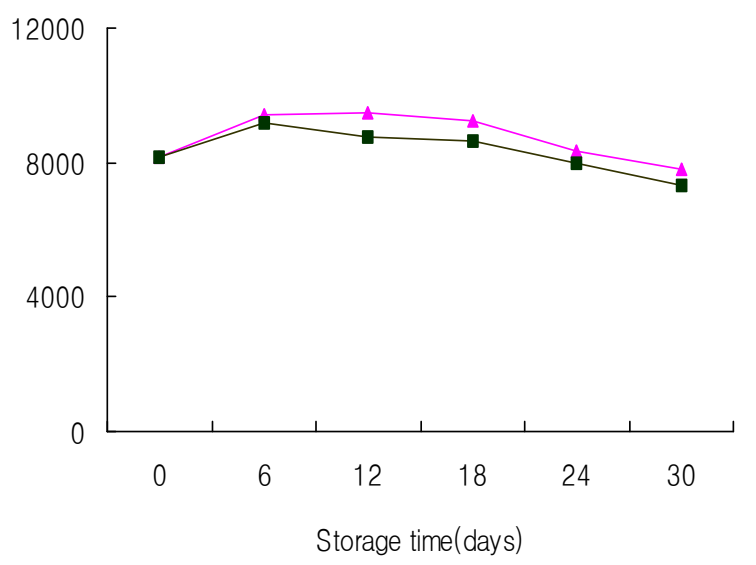

Fig. 8. Changes in the total free sugar content of the watermelon depending on its storage temperature and stalk shape during its storage. (A), $7^{\circ} \mathrm{C}$; (B), room temperature. $\mathbf{\square}$, watermelon without stalk; $\boldsymbol{\Delta}$, water melon with T-type stalk. There is no significant difference within columns, $\mathrm{p}<0.05$.

\section{저장일수와 꼭지처리에 따른 유리당총량 변화}

Hong 등(12)에 의하면 수박 여러 품종의 유리당은 sucrose, fructose, glucose 순으로 보고되고 있다. 본시험에 서는 저장기간 동안 각 유리당의 변화보다 꼭지유무에 따른 유리당 차이를 보는 것이 주목적이어서 이들 세 성분의 총량을 구하였다. 일반적으로 과실의 저장 중 당도(가용성 고형분)는 수확 후 후숙과정에서 전분 등 고분자 물질의 분해로 저장초기에는 증가하지만 그 이후에는 감소하는 것으로 알려져 있다(24). 본시험에서 유리당총량은 Fig. 8과 같이 초기에는 저장전 $8,133 \mathrm{mg} / 100 \mathrm{~g}$ 에서 증가하다가 저장 기간이 길어질수록 감소하였는데 각 저장온도에서의 꼭지 유무에 따른 유의차는 보이지 않았다.

이렇게 저장과 관련된 여러 요인들을 검토한 결과 동일 저장온도에서는 꼭지를 남기는 것과 제거하는 것 사이에는
어떠한 유의차도 보이지 않았다. 그러므로 꼭지유무가 저 장성에 영향을 미친다고 할 수 없으며, 따라서 수박을 수확 할 때 굳이 꼭지를 T형으로 남기고 수확하는 것은 개선되어 야 할 것이라 사료된다.

또 본 실험을 수행하면서 수박 수확시 꼭지를 제거하지 않고 관행처럼 $\mathrm{T}$ 형으로 잘랐을 때와 꼭지를 남기지 않고 작업할 경우의 시간을 측정해 본 결과, $1 \mathrm{ha}$ 기준으로 꼭지 를 T형으로 자르면서 수확할 경우는 15 시간, 제거할 경우 는 6 시간으로 수확노동력을 $60 \%$ 이상 줄일 수 있었음도 알 수 있었다. 따라서 라벨이 발달되어 품질요소를 추정 할 수 있는 현시대에서 수박이 꼭지를 제거한 상태에서 유통된다면 수확시 노동력을 크게 줄일 수 있고, 수송, 판매 등 유통면에서도 취급이 편리하여 비용도 많이 절감할 수 있으리라 생각된다. 


\section{요 약}

본 연구는 수박유통에 있어 수확시 꼭지를 $\mathrm{T}$ 형태로 자르 는 관행적 방법과 꼭지를 제거할 경우 저장성에 미치는 영향을 구명하고자 수행되었다. 실험에 사용한 수박의 평 균 무게는 $7.8 \mathrm{~kg}$ 이었고 각각 $7^{\circ} \mathrm{C}$ 와 실온에 저장하면서 여러 요인들을 조사하였다. 무게는 저장일수가 길어짐에 따라 감소하였는데 꼭지처리한 수박을 $7^{\circ} \mathrm{C}$ 에서 30 일 저장한 경 우 그 무게가 0.6 0.7\% 감소한 반면 실온에서는 1.9 2\% 감소하였으며 동일 온도조건하에서는 꼭지유무에 따른 유 의차는 없었다. 경도는 초기 $755 \mathrm{~g}$ 에서 저장일수가 경과함 에 따라 점차 감소하였으며 실온에서 저장하였을 경우 $542 \sim 549 \mathrm{~g}$ 으로 더 큰 감소폭을 보였으나 같은 온도조건하 에서는 꼭지유무에 따른 차이는 없었다. 저장기간 동안 $\mathrm{pH}$, 총산과 내부 수분은 모든 처리에서 큰 변화를 보이지 않았 으며, 가용성고형분은 실온에 저장한 것은 초기 평균 $11.3^{\circ} \mathrm{Brix}$ 에서 30 일 후에는 $9.3^{\circ} \mathrm{Brix}$ 로, 수박 내부의 적색도 는 초기 36.7 에서 저장후기에는 처리별로 31.7 33.6으로 감소하였으며, 유리당총량은 저장전 $8,133 \mathrm{mg} / 100 \mathrm{~g}$ 에서 초기에는 증가하다가 저장기간이 길어질수록 감소하였는 데 이들 변화 역시 동일저장조건에서의 꼭지유무에 따른 유의적 차이는 나타나지 않았다. 따라서 수박을 수확할 때 꼭지를 $\mathrm{T}$ 형태로 남긴 것과 제거한 것이 저장성에 미치는 영향은 없으므로 생산, 유통 등을 고려하여 꼭지를 제거하 는 것이 바람직하다고 판단된다.

\section{References}

1. KOSTAT (2014) 2013 Crop production statistics. Statistics Korea, Daejeon-si, Korea, p 68-69

2. RDA (2011) Standard food composition table. Rural Development Administration, Suwon-si, Korea, p 224

3. Lee WS (1994) Vegetable of Korea. Kyungpook National University Press, p 189-202

4. Penelope PV, Collins JK, Pair SD, Roberts W (2001) Lycopene content differs among red-fleshed watermelon cultivars. J Sci Food Agr, 81, 983-987

5. Park HW, Park JD, Cha HS, Kang CY, An DJ (2002) A study on distribution and packaging status of water melon in domestic markets. J Korea Society of Packaging Sci Tech, 8, 11-14

6. Lee SM (2010) Pallet system of watermelons. The monthly packaging world, 212, 52-57

7. Park S, Kang SC (2005) Evaluation of physiological changes in watermelon stalk during storage under various conditions of treatments after harvesting, Korean $\mathrm{J}$
Environ Agric, 24, 56-60

8. Eun JS, Han SK, Kang NH, Kim HC, Bae JH (2010) Effects of deep tillage before planting on physicochemical properties of soil, growth and fruit characteristics in cultivation of watermelon under plastic film house. J Environ Sci Int, 19, 130-134

9. Uhm MJ, Noh JJ, Chon HG, Kwon SW, Song YJ (2012) Application effect of organic fertilizer and chemical fertilizer on the watermelon growth and soil chemical properties in greenhouse. Korean J Environ Agric, 31, 1-8

10. Moon HC, Kim W, Choi MK, Kwon SH, Shin YK, Kim DH, Hwang CY (2011) Biological control of cotton aphid by Aphidius colemani (Hymenoptera: Braconidae) in watermelon greenhouses. Korean J Appl Entomol, 50, 79-82

11. Kang HJ, Kim YS, Han BT, Kim TI, Noh JW, Kim YG, Shin HD (2014) Alternative fungicide spraying for the control of powdery mildew caused by Sphaerotheca fusca on greenhouse watermelon (Citrullus lanatus). Res Plant Dis, 20, 31-36

12. Hong SP, Lim JY, Jeong EJ, Shin DH (2008) Physicochemical properties of watermelon according to cultivars. Korean J Food Preserv, 15, 706-710

13. Heo DJ, Kim SJ, Choi AR, Park HR, Lee SC (2013) Tyrosinase inhibitory activity and neuronal cell protection of hydrothermal extracts from watermelons. J Korean Soc Food Sci Nutr, 42, 1707-1711

14. Yishan Duan, Kim MA, Kim HS, Jang SH, Kang DS (2014) Screening of antioxidant activity from exocarp of watermelon (Citrullus vulgaris L.). J Env Sci Intern, 23, 1233-1239

15. Park CS, Kim ML (2010) Preparation and characterization of watermelon wine. Korean J Food Preserv, 17, 547-554

16. NFSMI (2011) Watermelon information sheet. National Food Service Management Institute, The University of Mississippi, MS, USA, p 1-2

17. MFDS (2014) Food Code. Method 9-1. Ministry of Food and Drug Safety, Cheongju-si, Korea

18. AOAC (2000) Official Methods of Analysis of AOAC Intl. (17th ed), Vol. II, Method 942.15. Association of Official Analytical Chemists, Gathersburg, Maryland, USA, p 11

19. Chung MJ, Shin JH, Lee SJ, Hong SK, Kang HJ, Sung NJ (1998) Chemical compounds of wild and cultivated horned rampion, Phyteuma japonicum Miq. Korean J Food Sci Technol, 26, 437-443. 
20. Choi JH, Jang JG, Park KD, Park MH, Oh SK (1981) High performance liquid chromatographic determination of free sugars in Ginseng and its products. Korean J Food Sci Technol, 13, 107-113

21. NAQS (2014) Agricultural Products Standardization, No. 2081., National Agricultural Products Quality Management Service, Gimcheon-si, Korea

22. Veazie P, Collins JK (2004) Flesh quality and lycopene stability of fresh-cut watermelon. Postharvest Biol Technol, 31, 159-166

23. Chisholm DN, Picha DH (1986) Effect of storage temperature on sugar and organic acid contents of watermelon. HortSci, 21, 1031-1033

24. Hwang TY, Son SM, Lee CY, Moon KD (2001) Quality changes of fresh-cut packaged Fuji apples during storage. Korean J Food Sci Technol, 33, 469-473 